\title{
Intraspecific evolution of
}

Rhizoctonia solani AG-1 IA

associated with soybean and rice in Brazil based on polymorphisms at the ITS-5.8S rDNA operon

\section{Journal Article}

Author(s):

Ciampi, Maisa B.; Kuramae, Eiko E.; Fenille, Roseli C.; Meyer, Maurício C.; Souza, Nilton L.; Ceresini, Paulo Cezar

Publication date:

2005-10

Permanent link:

https://doi.org/10.3929/ethz-b-000030754

Rights / license:

In Copyright - Non-Commercial Use Permitted

Originally published in:

European Journal of Plant Pathology 113(2), https://doi.org/10.1007/s10658-005-2231-7 


\title{
Intraspecific evolution of Rhizoctonia solani AG-1 IA associated with soybean and rice in Brazil based on polymorphisms at the ITS-5.8S rDNA operon
}

\author{
Maisa B. Ciampi ${ }^{1}$, Eiko E. Kuramae ${ }^{2}$, Roseli C. Fenille ${ }^{3}$, Maurício C. Meyer ${ }^{3}$, Nilton L. Souza ${ }^{3}$ and \\ Paulo C. Ceresini ${ }^{4,5, *}$ \\ ${ }^{1}$ UNESP - Universidade Estadual Paulista - Campus de Jaboticabal, SP 14884-900, Brazil; ${ }^{2}$ Centraalbureau \\ voor Schimmelcultures - CBS, 3584 CT, Utrecht, The Netherlands; ${ }^{3}$ UNESP - Universidade Estadual \\ Paulista - Campus de Botucatu, SP 18610-970, Brazil; ${ }^{4}$ UNESP - Universidade Estadual Paulista - Campus \\ de Ilha Solteira, SP 15385-000, Brazil; ${ }^{5}$ Swiss Federal Institute of Technology - ETHZ, Institute of Plant \\ Sciences, 8092, Zurich, Switzerland;*Author for correspondence (E-mail: paulo.ceresini@ipw.agrl.ethz.ch)
}

Accepted 11 August 2005

Key words: anastomosis group, foliar blight, Thanatephorus cucumeris

\begin{abstract}
Rhizoctonia solani AG-1 IA causes leaf blight on soybean and rice. Despite the fact that $R$. solani AG-1 IA is a major pathogen affecting soybean and rice in Brazil and elsewhere in the world, little information is available on its genetic diversity and evolution. This study was an attempt to reveal the origin, and the patterns of movement and amplification of epidemiologically significant genotypes of $R$. solani AG-1 IA from soybean and rice in Brazil. For inferring intraspecific evolution of $R$. solani AG-1 IA sampled from soybean and rice, networks of ITS-5.8S rDNA sequencing haplotypes were built using the statistical parsimony algorithm from Clement et al. (2000) Molecular Ecology 9: 1657-1660. Higher haplotype diversity (Nei M 1987, Molecular Evolutionary Genetics Columbia University Press, New york: 512p.) was observed for the Brazilian soybean sample of $R$. solani AG-1 IA (0.827) in comparison with the rest of the world sample (0.431). Within the south-central American clade (3-2), four haplotypes of R. solani AG-1 IA from Mato Grosso, one from Tocantins, one from Maranhão, and one from Cuba occupied the tips of the network, indicating recent origin. The putative ancestral haplotypes had probably originated either from Mato Grosso or Maranhão States. While 16 distinct haplotypes were found in a sample of 32 soybean isolates of the pathogen, the entire rice sample $(n=20)$ was represented by a single haplotype (haplotype 5), with a worldwide distribution. The results from nested-cladistic analysis indicated restricted gene flow with isolation by distance (or restricted dispersal by distance in nonsexual species) for the south-central American clade (3-2), mainly composed by soybean haplotypes.
\end{abstract}

\section{Introduction}

The soilborne Basidiomycete fungus Thanatephorus cucumeris [anamorph $=$ Rhizoctonia solani] is reported to cause economically important diseases on soybean crops throughout the world (Jones and Belmar, 1989; Naito et al., 1995; Yang et al., 1990). Symptoms observed on soybean plants and associated with $R$. solani infection include damping- off, root rot, hypocotyl rot, leaf blight and aerial blight. While damping-off, root and hypocotyl rots are mainly associated with $R$. solani anastomosis group (AG) 2-2 IIIB or AG-4, the foliar diseases are associated with AG-1 IA, AG-1 IB or AG-2-3.

Particularly important, the foliar blight caused by $R$. solani AG-1-IA on soybean has a worldwide significance (Jones and Belmar, 1989; Yang et al., 1990; Naito et al., 1995). In Brazil, a natural trend of 
soybean crop expansion towards new areas in northern and northeastern Brazil, where higher temperatures and humidity conditions are favourable to the pathogen, has contributed to the increasing importance of the foliar blight (Almeida et al., 1997). There are recent reports of yield losses ranging from 31 up to $60 \%$ in newly established soybean areas of Maranhão, Piauí, Tocantins, Pará, and Roraima States (Meyer and Yorinori, 1999).

Historically, the first world report of soybean foliar blight was from 1918 in the Philippines (Sinclair and Backman, 1989). In Brazil, the first report of $R$. solani AG-1 associated with a foliar disease on soybeans was in the 80 s by Bolkan and Ribeiro (1985), in Brasília, the Federal District (central-western Brazil). In the 90s the disease was reported as occurring in southern Maranhão (north-eastern Brazil) (Meyer, 2001). Incidence of foliar blight caused by AG-1 IA has also been extensively reported in irrigated areas of the Cerrado grasslands of Mato Grosso, where soybean is cropped mainly for seed production during fall/ winter season (Fenille et al., 2002). The disease has also been reported in Louisiana (Stroube, 1954; Yang et al., 1990) and in Texas, USA (Jones and Belmar, 1989).

Besides causing leaf blight on soybean, R. solani AG-1 IA causes sheath blight and sheath spot on rice (Jones and Belmar, 1989). The fungus was first described in Japan at the beginning of the century (Kozaka, 1975) and has been subsequently reported from most rice-growing regions of the world (Rosewich et al., 1999). In Brazil, the first report of $R$. solani AG-1 associated with sheath blight on rice was from 1967 by Amaral et al. (1979), in São Paulo State (southern Brazil). The rotation rice-soybean has contributed to the increase in disease incidence of AG-1 IA on both crops (Harville et al., 1996), because most of the rice and soybean cultivars are susceptible to $R$. solani. Cross-infection studies showed that soybean and rice isolates of $R$. solani AG-1 IA are pathogenic to both hosts (Souza et al., 2005). Differences on host reaction to soybean isolates of $R$. solani AG-1 IA have also been reported but little is known about differences on pathogen virulence/aggressiveness (Meyer, 2001).

Despite the fact that $R$. solani AG-1 IA is amongst the most important pathogens affecting soybean and rice in Brazil, little information is available on its genetic diversity and patterns of molecular evolution. In Brazil, the genetic diversity of $R$ solani AG1-IA from soybean was characterized using RAPD markers, where at least 26 different RAPD profiles were identified among 62 isolates (Fenille et al., 2002). There was evidence for an expressive clonal component in this population of the pathogen. About $37 \%$ of the isolates of $R$. solani AG-1 IA were probable clones (Campos and Ceresini, 2005). However, the deviations of the strict association between the somatically compatible groups and the RAPD groups observed are consistent with recombination. No attempt for characterizing the geographical structuring of Brazilian AG-1 IA populations from soybean has so far been made.

High similarity was found among rDNA sequences of AG-1 IA isolates, reaching 95.1-100\% in the ITS region (Fenille et al., 2003). There is no information on patterns of DNA sequence variation in $R$. solani AG-1 IA from rice. DNA sequence variation has the benefit that the history of the alleles or haplotypes can be inferred through phylogenetic methods. By knowing the phylogenetic history of the alleles at a locus, there is potential for separating the past demographic events among a group of populations (such as founder effects) from current patterns resulting from the equilibrium between genetic drift/gene flow (Templeton, 1998).

In Rhizoctonia, as in several other fungi examples, the DNA sequencing variation at the ribosomal RNA coding cistron (rDNA) has been extensively used for molecular systematics and phylogenetics studies (White et al., 1990; Adams 1996; Gonzales et al., 2001). The rDNA sequencing data has also been utilized for population genetics studies in fungi (Carbone et al., 1999; James et al., 2001). Ribosomal genes are tandemly repeated within the same nucleus, and the paralogs are usually identical due to a poorly understood process of concerted evolution (Hillis et al., 1991). Recombination of rDNA genes is usually suppressed (Liao, 1999), which is an important drawback when choosing rDNA markers for population genetics studies aiming to detect recombination in fungal populations. However, within-individual diversity for the rDNA-ITS region has been reported for fungi (Hughe and Petersen, 2001; James et al., 2001).

Diversity/evolutionary studies can be important for understanding the pathology and ecology of 
R. solani AG-1 IA and of other pathosystems as well. We would like to point out a few caveats of molecular evolutionary approaches of interest for plant pathology, reviewed by Kohn (2004) and addressed by Carbone and Kohn (2001), Couch and Kohn (2002), Phillips et. al. (2002), and Milgroom and Peever (2003). Firstly, a multilocus phylogenetic analysis on a contemporary sample is relevant to ultimately infer pathogen evolution. One important example is the inference of host jumps. Secondly, phylogenetics and genealogical interpretation of DNA sequence data from multiple genomic regions of a plant pathogen is essential for species delimitation and within-species population genetics conjectures. Accurately defined species are the key for quarantine strategies; however, in the absence of necessary morphological traits for taxonomic diagnosis, the knowledge of the closest relatives of a species helps to predict significant biological characteristics. Thirdly, detection of phylogenetic conflicts may be indicative of recombination or of mutational hotspots. In the perspective of epidemiology and disease control, recombination can be an important way for pathogens to combine, in a single genotype, traits such as fungicide resistance, virulence or enhanced tolerance to environments. Finally, the combination of comparative genomics with powerful statistical methods can be explored to address basic questions on the origin, movement and amplification of epidemiologically significant genotypes of a plant pathogen. This last point was the main focus of our study on the evolution of $R$. solani AG-1 IA looking at the rDNA region.

This study describes rDNA ITS1-5.8S-ITS2 sequencing variation in $R$. solani AG-1 IA causing aerial blight on soybeans and sheath blight on rice in Brazil. We tested the hypothesis of no geographical association of ITS-5.8S $R$. solani AG-1 IA haplotypes within the nested clades, which would indicate panmixia in a sexual population or extensive dispersal in a non-sexual population.

In general, the fungus $R$. solani AG-1 IA is assumed to be sexual on soybeans. Basidiospores produced by the sexual stage of the fungus ( $T$. cucumeris) are considered an important source of inoculum of the pathogen (Meyer, 2001). In contrast, the asexual stage of the fungus is traditionally viewed as predominant in the life cycle of the organism on rice (Rosewich et al., 1999). However, there is evidence for recombination associated with sexual reproduction among field isolates of $T$. cucumeris from rice (anamorph $=R$. solani AG-1 IA) in Texas (Rosewich et al., 1999) and in India (Linde et al., 2005). A recombining structure was also reported for populations of T. cucumeris from potatoes (anamorph $=$ AG-3 PT) in north Carolina (Ceresini et al., 2002). Although the mating system of $T$. cucumeris is not known, this strong evidence for recombination indicates that sexual spores play an important role in the fungal life history contributing to the genetic diversity and structure of field populations of the pathogen.

We also explored the group's diversity comparing the rDNA data from Brazilian isolates with the data that exists for other isolates obtained from throughout the world. This study used a nested phylogenetic approach that has the potential of separating population structure from population history. To highlight the importance of this study, this was an attempt to reveal the origin and the patterns of movement and amplification of epidemiologically significant genotypes of $R$. solani AG1 IA from soybean in Brazil.

\section{Materials and methods}

\section{Isolates and haplotypes sample}

In this study, two population samples of $R$. solani AG-1 IA were analyzed: the Brazilian sample, composed of 31 isolates randomly selected from a soybean foliar blight population from centralwestern [Mato Grosso (MT) and Tocantins (TO) States] and northern Brazil [Maranhão (MA) State] and four rice sheath blight isolates from TO, and by a world sample, composed of 29 isolates obtained from several hosts in Japan (8 isolates), Philippines (1), Vietnam (1), Ivory Coast (1), Washington, USA (2), Stuttgart Arkansas, USA (13), and Havana, Cuba (3). The origin of the samples is described in Table 1. These population samples of $R$. solani AG-1 IA were examined using sequence analysis of the ITS1-5.8S-ITS2 rDNA operon. As few isolates of AG-1 IA from around the world were unavailable, their ITS1-5.8S-ITS2 sequences were retrieved straight from NCBI National Center for Biotechnology Information (Bethesda, MD, USA) for comparison purposes. Anastomosis grouping and pathogenicity of Brazilian isolates of $R$. solani to soybean and rice were 


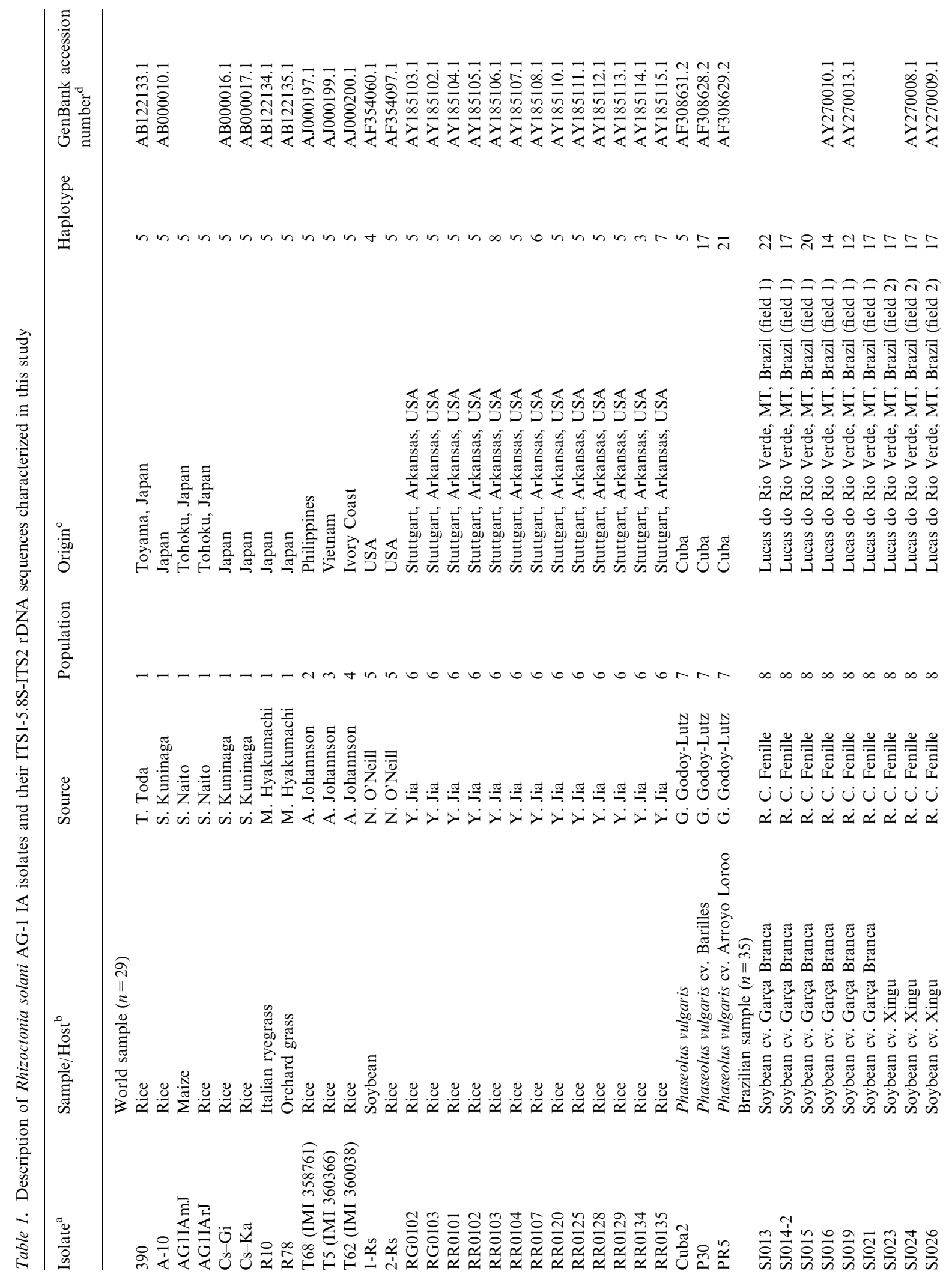




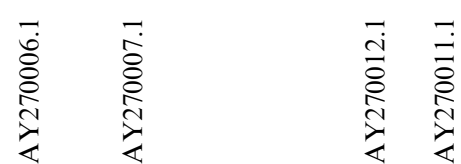

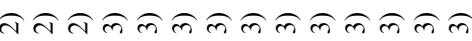

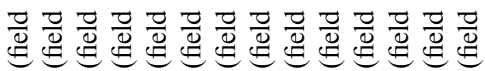

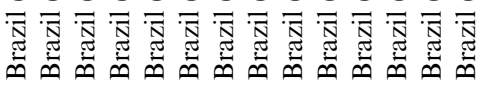

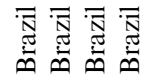

武

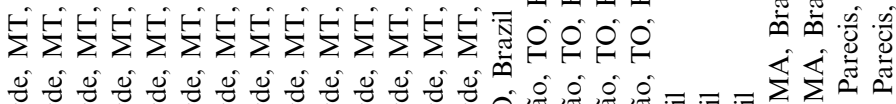

Hi

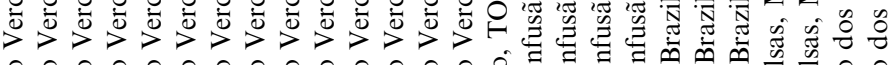

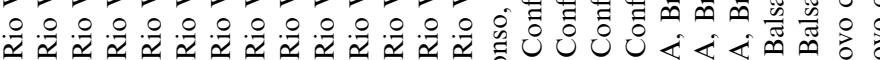

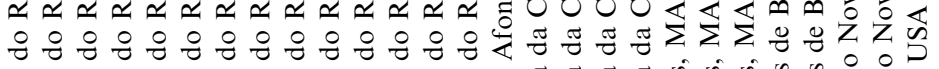

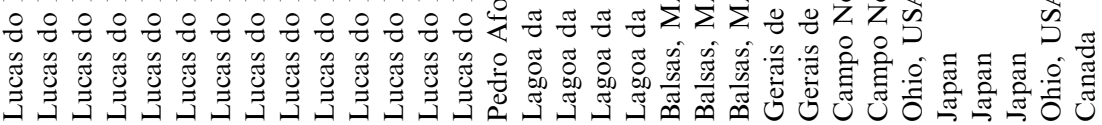

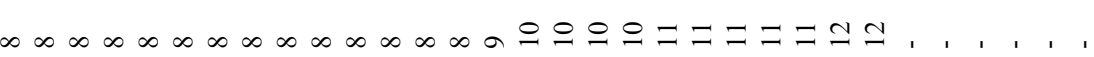

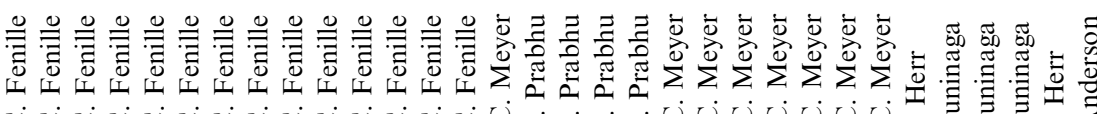

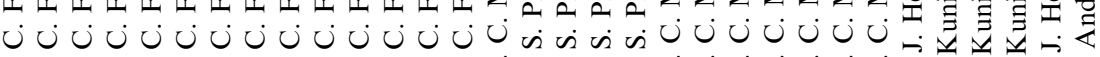

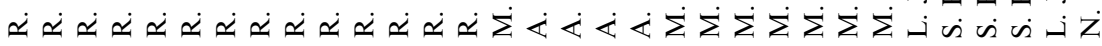

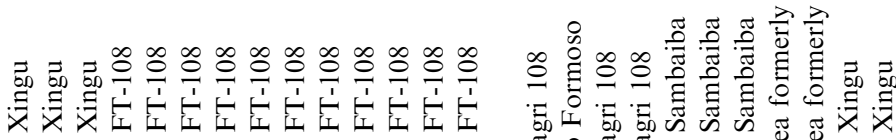

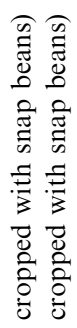

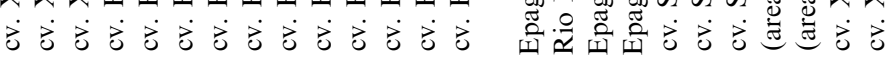
$\begin{array}{lll} & \\ & \end{array}$

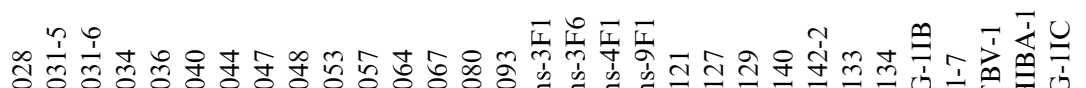

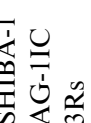


determined previously by Fenille et al., (2002, 2003), Meyer (2001) and Souza et al. (2005).

DNA extraction, polymerase chain reaction and ITS1-5.8S-ITS2 rDNA sequencing

The genomic DNA extraction of $R$. solani AG-1 IA isolates, polymerase chain reaction and ITS15.8S-ITS2 rDNA sequencing and the sequences assembling were performed according to Fenille et al. (2003).

\section{Cloning}

There was one single case of heterogeneity in the sequence of the PCR amplicon from isolate SJ31. To separate distinct ITS1-5.8S-ITS2 alleles within this heterogeneous PCR reaction, amplicons were cloned into the PCR2.1-TOPO ${ }^{\circledR}$ vector (Invitrogen, San Diego). Plasmids from selected recombinant One Shot ${ }^{\circledR}$ DH5a ${ }^{\mathrm{TM}}-\mathrm{T} 1 \mathrm{R}$ Escherichia coli (Invitrogen, San Diego) were extracted from each sample and purified using QIAprep Spin Miniprep Kit $\left(\mathrm{QIAGEN}^{\circledR}\right)$. The primers listed above were used to reamplify and sequence the clones from PCR2.1-TOPO ${ }^{\circledR}$.

\section{Phylogenetic analysis}

The ITS sequences and 5.8S rDNA data of all isolates were aligned using the computer software package CLUSTAL X (Thompson et al., 1997). The tree showing the phylogenetic relatedness between isolates was constructed from distance matrix values by the neighbour-joining method and 1000 bootstrap values were calculated using the software above.

\section{Measures of nucleotide diversity and intragenic recombination}

Nucleotide diversity or the average number of differences per site between two homologous sequences $(\pi)$ was calculated using the programme DNASP (Rozas and Rozas, 1999) according to the equation 10.5 of Nei (1987). Diversities were calculated for the population of AG-1 as a whole as well as separately by their origin: from Brazil or from a world sample. For comparison purposes, sequences of the ITS1-5.8S-ITS2 region from isolates of $R$. solani AG-1 IB and AG-1 IC from several hosts obtained from the GenBank ${ }^{\circledR}$ (National Center for Biotechnology Information, Bethesda, MD, USA) were included in the analysis (Table 1). The spectrum of polymorphism along the locus was measured and represented as $\pi$ along a sliding window of 5 positions. Recombination parameters were estimated according to Hudson and Kaplan (1985).

Intraspecific evolution of $\mathrm{R}$. solani AG-1 IA inferred by analysis of individual gene reticulograms

For inferring intraspecific evolution of $R$. solani AG-1 IA sampled from soybean and rice, networks of haplotypes were built using the algorithm proposed by Posada and Crandall (2001). Sequences of the ITS1-5.8S-ITS2 region from isolates of $R$. solani AG-1 IB and AG-1 IC (Table 1) were included in the analysis, as an outgroup. This method estimates the maximum number or differences between haplotypes as a result of single substitutions in a single site with a statistical significance level of $95 \%$. This is called limit of parsimony (or limit of parsimony connection). Then, haplotypes differing by only one change are connected, and finally those differing by two, three and so on until all the haplotypes are included in a single network. The estimation of the phylogeny from DNA sequences was implemented by the computer programme TCS (Clement et al., 2000).

\section{Nested clade analysis}

The nested clade analysis (NCA) of AG-1 IA haplotypes was performed with the objective of discriminating between phylogenetic patterns resulting from historical events (for example, past fragmentation, expansion, colonization) from those due to recurrent gene flow (Templeton, 1998). This analysis utilizes both a phylogeny and the geographical distribution of haplotypes or haplotype clades. The NCA was done using the computer program GeoDis v.2.0 (Posada et al., 2000) by considering the haplotype network (phylogeny) obtained by statistical parsimony analysis as described above. This analysis divides the phylogeny in nested clades of $n$ steps, where $n$ is equal to the number of mutations connecting the haplotypes of a clade. For each clade there is a geographic centre by which all the individuals are 
centred. Two quantitative measures of how withinclade haplotypes are geographically dispersed were used, as described by Templeton (1998): the clade distance $=D_{\mathrm{c}}(X)$, which describes the average distance of each haplotype within clade $X$ from the geographic centre of clade $X$; and the nested clade distance $=D_{\mathrm{n}}(X)$, which similarly describes the average distance of each haplotype within clade $X$ from the geographic centre of the next more inclusive clade within which the clade $X$ is nested. Accordingly, within each nested category and for both types of distances $\left(D_{\mathrm{c}}\right.$ and $\left.D_{\mathrm{n}}\right)$, we calculated and determined the significance of the average interior distance minus the average tip distance $\left[(\text { Int-Tip })_{\mathrm{c}}\right.$ and $\left.(\text { Int-Tip })_{\mathrm{n}}\right]$. Contrasts of interior versus tip clades within a nested clade tend strongly to be contrasts of older versus younger clades. Haplotypes were assigned to the following populations with the correspondent geographical coordinates: 1, Japan $\left(44^{\circ} 43^{\prime} 00^{\prime \prime} \mathrm{N} 142^{\circ} 30^{\prime}\right.$ $\left.00^{\prime \prime} \mathrm{E}\right) ; \quad 2$, Philippines $\left(13^{\circ} 00^{\prime} 00^{\prime \prime} \mathrm{N} 122^{\circ} 00^{\prime}\right.$ $\left.00^{\prime \prime} \mathrm{E}\right)$; 3, Vietnam $\left(20^{\circ} 25^{\prime} 00^{\prime \prime} \mathrm{N} 105^{\circ} 30^{\prime} 00^{\prime \prime} \mathrm{E}\right)$; 4, Ivory Coast $\left(8^{\circ} 00^{\prime} 00^{\prime \prime} \mathrm{N} 05^{\circ} 00^{\prime} 00^{\prime \prime} \mathrm{W}\right)$; 5, Washington, USA $\left(38^{\circ} 00^{\prime} 00^{\prime \prime} \mathrm{N} 97^{\circ} 00^{\prime} 00^{\prime \prime} \mathrm{W}\right)$; 6 , Stuttgart Arkansas, USA $\left(34^{\circ} 30^{\prime} 01^{\prime \prime} \mathrm{N}\right.$ $\left.91^{\circ} 33^{\prime} 09^{\prime \prime} \mathrm{W}\right)$; 7, Havana, Cuba (23 $07^{\prime} 50^{\prime \prime} \mathrm{N}$ $\left.82^{\circ} 21^{\prime} 51^{\prime \prime} \mathrm{W}\right) ; 8$, Lucas do Rio Verde, MT, Brazil $\left(13^{\circ} 03^{\prime} 45^{\prime \prime} \mathrm{S} 55^{\circ} 53^{\prime} 45^{\prime \prime} \mathrm{W}\right)$; 9, Pedro Afonso, TO, Brazil ( $\left.85^{\circ} 8^{\prime} 45^{\prime \prime} \mathrm{S} 48^{\circ} 11^{\prime} 15^{\prime \prime} \mathrm{W}\right)$; 10, Lagoa da Confusão, TO, Brazil (10 48 $01^{\prime \prime} \mathrm{S} 49^{\circ} 38^{\prime}$ $\left.53^{\prime \prime} \mathrm{W}\right)$; 11, Balsas, MA, Brazil $\left(7^{\circ} 31^{\prime} 15^{\prime \prime} \mathrm{S}\right.$ $46^{\circ} 01^{\prime} 15^{\prime \prime} \mathrm{W}$ ); and 12, Campo Novo do Parecis, MT, Brazil $\left(13^{\circ} 41^{\prime} 15^{\prime \prime} \mathrm{S} 57^{\circ} 53^{\prime} 45^{\prime \prime} \mathrm{W}\right)$. Clade distances were calculated using a distance matrix among populations based on geographic coordinates. A test of 1000 permutations of population assignments to haplotypes was used to determine the significance of larger or smaller values of $D_{\mathrm{c}}$, $D_{\mathrm{n}},(\text { Int-Tip) })_{\mathrm{c}}$ and $(\text { Int-Tip) })_{\mathrm{n}}$ than would be expected for a null hypothesis of random geographical association of haplotypes (Templeton, 1998).

\section{Results}

For the total population of 35 strains sampled, 16 unique ITS1-5.8S-ITS2 haplotypes were identified for the Brazilian sample, and only eight in the sample from the rest of the world, composed of 29 strains. The haplotype (gene) diversity (according to Nei, 1987) was $0.827 \pm 0.059$ for the Brazilian sample whereas for the world sample the haplotype diversity was $0.431 \pm 0.116$. The average number of substitutions per site ( $\pi$ value) between two random samples was 0.00917 for the Brazilian sample and 0.00270 for the world sample. The average number of nucleotide differences $(k)$ was 5.034 [with a total variance $V(k)$ of 1.777] for the Brazilian sample in contrast with 1.488 $(V(k)=0.035)$, for the world sample.

Of the total aligned $549 \mathrm{bp}$ positions (excluding sites with alignment gaps) at ITS1-5.8S-ITS2, 30 (or $5.46 \%$ ) were polymorphic for the Brazilian sample and only 16 out of 550 bp (or $2.91 \%$ ) were variable for the world sample. Of the total variable positions for both Brazilian and world samples, 20 of these were unique haplotypes or singletons (Table 1).

The spectrum of polymorphism along the locus (which was measured as $\pi$ along a sliding window of $5 \mathrm{bp}$ size and step size of $2 \mathrm{bp}$; Figure 1) contrasts the high nucleotide diversity of the combined sample of AG-1 IA, IB and IC in comparison with the total sample of AG-1 IA and either the Brazilian or the world sample separately. Most of the nucleotide diversity was observed between samples of AG-1 IA, IB and IC of $R$. solani. For AG-1 IA particularly, within-sample comparison indicated higher nucleotide diversity for the Brazilian sample than for the world sample. A single recombination event was detected for AG-1 IA from Brazil, between sites 136 and 188. The estimate of $R$ per gene was equal to 4.6 , while the $R$-value between adjacent sites was 0.0081 .

The construction of the haplotypes network for the ITS1-5.8S-ITS2 region was done by statistical parsimony (Figure 2), where degrees of evolutionary relationship were represented by mutational connections. There was no mutational connection linking any of the ITS1-5.8S-ITS2 haplotypes of $R$. solani AG-1 IA and IB or IC (data not shown). There was also an indication that several other haplotypes were not sampled from the populations of AG1 IA as indicated by black dots in the network (Figure 2).

Considering the sample of AG-1 IA exclusively, closely related ITS1-5.8S-ITS2 haplotypes were separated by a maximum of 10 connection steps, at $P=95 \%$. This method allowed also for the identification of the ancestral haplotypes based on both their frequency in the population and 

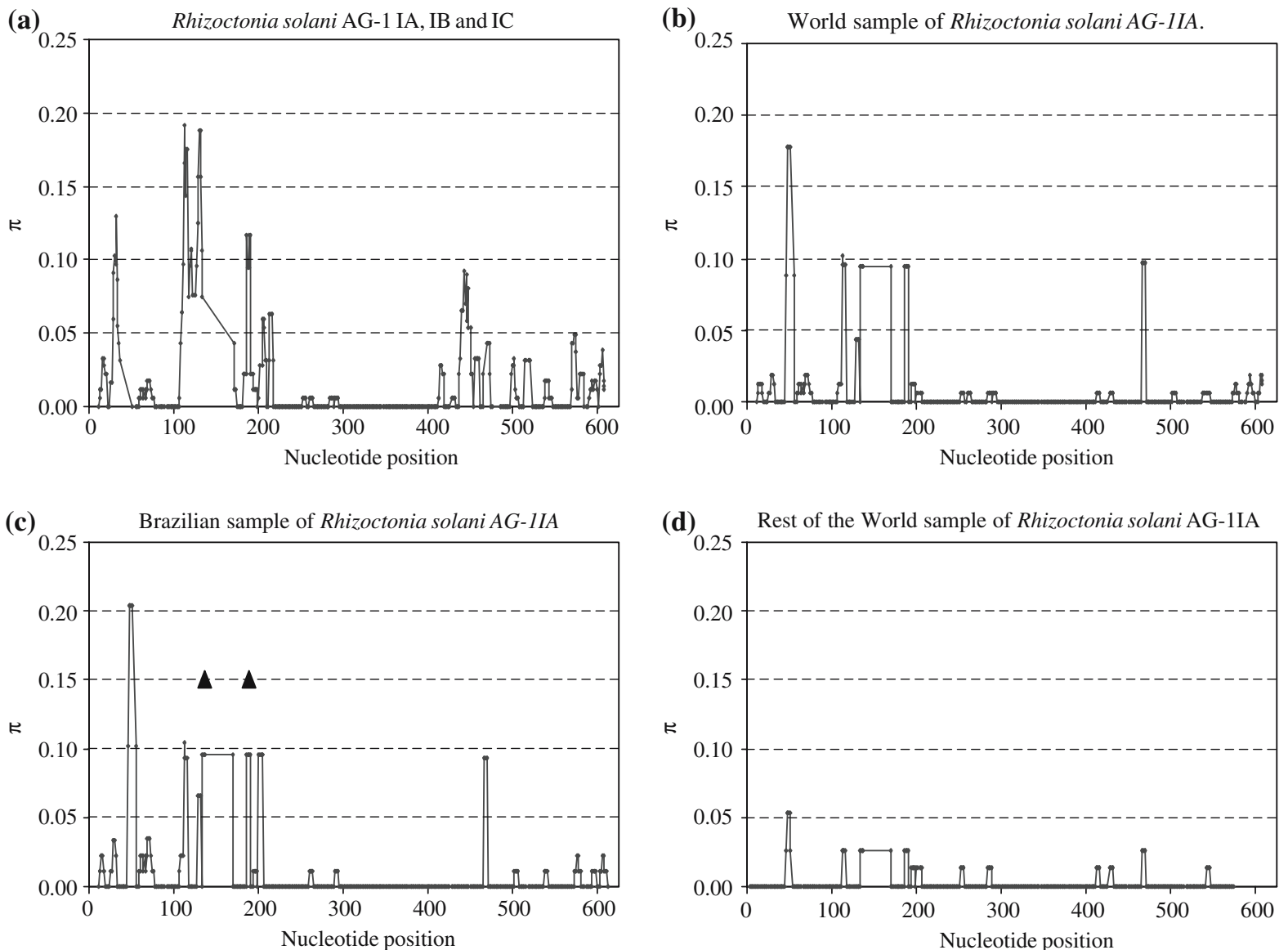

Figure 1. Spectrum of polymorphism within the rDNA intergenic region depicted as sliding window of size 5 bp and step size of 2 bp. $\pi$ describes the average number of pairwise substitutions at a particular site among the total sample of AG-1 IA, IB and IC (a); the World sample of Rhizoctonia solani AG-1 IA (b), the Brazilian sample (c), and the rest of world sample of AG-1 IA (d). The abscissa represents the position along the spacer region about which the sliding window is centred. Dark triangles on Figurelc indicate a recombination event that has been detected between sites 136 and 188, according to Hudson and Kaplan (1985).

mutational connections with other haplotypes. The most frequent allele is, theoretically, the oldest one too and could be identified as the most interior to the network, showing more than one mutational connection (Posada and Crandall, 2001). The haplotype 5, within clade 3-1, was the most frequent allele in the entire population, representing $37.5 \%(n=24)$ of the total sample of 64 haplotypes. Most of the AG-1 IA isolates from where the haplotype 5 was detected have originated from rice samples $(n=20)$ with a worldwide distribution (Brazil, Ivory Coast, Japan, Philippines, USA and Vietnam). However, the AG-1 IA ITS-5.8S haplotype 5 was also associated with other crops, like beans (Cuba), Italian ryegrass, maize and orchard grass (Japan).
An outside origin for the AG1 IA haplotypes detected on soybeans in Brazil could not be rejected as few haplotypes from soybean (SJ047, SJ048, SJ057, and SJ067 = haplotype 9; SJ040 = haplotype 10 ; and SJ080 = haplotype 11) were closely related to the widespread haplotype 5 , composing the same 2-step clade 2-3 from clade 3-1.

Considering the south-central American clade (3-2), four haplotypes of $R$. solani AG-1 IA from Mato Grosso (central-western), one from Maranhão (northern Brazil), one from Tocantins (central-western) and one from Cuba occupied the tips of the network, indicating recent origin. The putative ancestral haplotype 17 had either Mato Grosso or Maranhão State origin. Despite the high haplotype diversity within $R$. solani AG-1 IA 


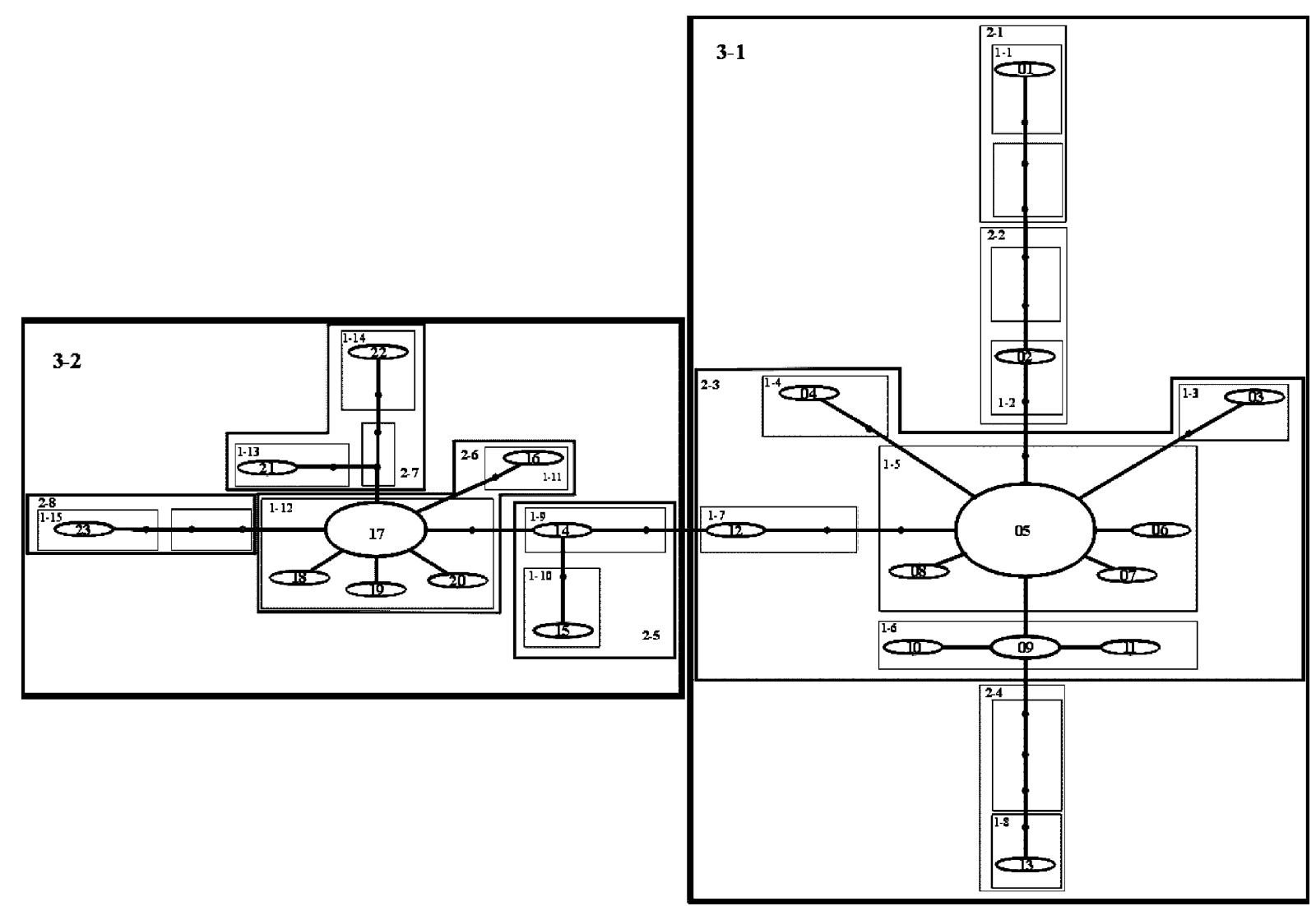

Figure 2. Nesting of the ITS-5.8S rDNA haplotype networks of $R$. solani AG-1 IA. The network was constructed using the statistical parsimony algorithm implemented by TCS (Clement et al., 2000). Geometric figures group haplotypes and the area of each figure represents the relative frequency of haplotypes in the population. Black dots indicate mutant haplotypes not sampled from the population. The $(n+1) c s t e p$ clades are shown in bold, where $n$ refers to the nesting level and $c$ is a counter for the number of clades at that level. Narrow lined boxes enclose one-step clades, which are designated by 1-c; thicker lined boxes enclose two-step clades (2-c); wide-thicker lined boxes enclose three-step clades (3-c). The nesting design followed rules stated by Templeton (1998).

from Brazil, the south-central American haplotype 17 was evolutionarily considered the oldest one within the clade 3-2. This was based on its frequency $(21.9 \% ; n=14)$ and the amount of mutational connections linking haplotype 17 with most of the other Brazilian AG-1 IA haplotypes from soybean and a single Cuban haplotype from bean.

\section{Discussion}

The first important observation from our research was that populations of $R$. solani AG-1-IA from soybean and rice exhibited distinct patterns of nucleotide diversity. While 16 distinct haplotypes were found in a sample of 32 soybean isolates of the pathogen, the entire rice sample was repre- sented by a single haplotype (haplotype 5, with a worldwide distribution). This indicated a highly polymorphic soybean sample of the pathogen as opposed to a nearly clonal rice sample of AG-1 IA. Evidence for clonality was also demonstrated by Rosewich et al. (1999) and by Pascual et al. (2000), who reported the occurrence of repeated genotypes of $R$. solani AG-1-IA in the same and in different rice and maize fields, respectively.

A reasonable explanation for such distinction on the genetic diversity between the soybean and rice samples of $R$. solani AG-1 IA could be related to the remarkable differences on the biology, pathology and epidemiology of the pathogen. The fungus $R$. solani AG-1 IA from rice survives and is disseminated primarily by the asexual production of sclerotia and/or vegetative mycelia. The asexual 
stage is traditionally viewed as predominant in the life cycle of the organism in the US (Rosewich et al., 1999). The sexual structures (consisting of basidia and basidiospores) have been predominantly observed on soybean leaf blight disease in northern Brazil (Meyer, 2001; Fenille et al., 2002, 2003), and also on alternative hosts, such as sorghum and corn (Jones and Belmar, 1989), but rarely detected on rice (Rosewich et al., 1999). In contrast to rice sheath blight, the dissemination of the soybean foliar blight pathogen may occur through meiotic basidiospores. In regions with high temperatures and humidity throughout the year, such as in northern Brazil, AG-1 IA basidiospores are considered important source of inoculum (Meyer, 2001).

The widespread distribution of the ITS-5.8S haplotype 5 of $R$. solani AG-1 IA suggests the existence of a mechanism that ensures a high level of dispersal between geographic populations of clonally reproduced fungal material. Traditional explanations for the migration/spread of clonal structures of soilborne plant pathogenic fungi over long distances favour physical means, such as via contaminated seeds of rice and/or soybean or by the transport of sclerotia or other fungal structures in soil or infected organic matter on machinery or other equipment (Jones and Belmar 1989, Meyer and Yorinori, 1999). This long-distance movement of $R$. solani AG-1 IA could be achieved also by the sharing of equipment among growers from distant but contiguous growing regions. Migration of growers and movement of their agricultural equipment to the newly established growing regions has characterized the soybean expansion from the traditional southern states growing areas of Rio Grande do Sul and Paraná to the Cerrado areas of central-western (Mato Grosso do Sul, Mato Grosso and Goiás), northern (Pará and Roraima) and north-eastern Brazil (Maranhão and Bahia) (Menezes, 2001). However, there is no evidence supporting the existence of a mechanism that ensures the establishment of $R$. solani AG-1 IA genotypes intermediate between those of geographic populations in Brazil. The introduction of migrant genotypes of $R$. solani into recipient areas has been reported for the $R$. solani - AG-3 PT potato pathosystem through importing of infected potato seed tubers into production areas in north Carolina (NC). In addition, of the 10 common genotypes found in both source and recipient populations, seven were amongst the most frequent genotypes recovered from soil in $\mathrm{NC}$ (Ceresini et al., 2002, 2003).

The other important result of this paper is based on the nested cladistic analysis (NCA) for studying aspects of the recent evolution of $R$. solani AG-1 IA on rice and soybean. Although new for a $R h i-$ zoctonia system, this approach has been previously applied to populations of Mycosphaerella graminicola from wheat (Banke et al., 2004) and to populations of the rice blast pathogen Pyricularia oryzae (Kohn, 2004). Our main goal with this research was to reveal, by using NCA, which historical events have interfered with the evolution of the $R$. solani AG-1 IA - rice and soybean pathosystems. The main hypothesis about $R$. solani AG-1 IA population history tested that no geographical association of ITS-5.8S haplotypes exists within the nested clades, which would indicate panmixia in a sexual population or extensive dispersal in a non-sexual population. The results from NCA presented in Figure 3 indicate restricted gene flow with isolation by distance (or restricted dispersal by distance in non-sexual species). The clade 3-1 was characterized basically by haplotypes of $R$. solani AG-1 IA from rice, with a worldwide distribution, whereas the clade 3-2 was mainly composed by haplotypes from soybean, with a distribution restricted to south-central America. These results support the contrasting hypothesis of the geographical association of Brazilian haplotypes of ITS1-5.8S-ITS2 from R. solani AG-1 IA, indicating regionally recurrent, but worldwide-restricted gene flow for clade 3-2 (Figure 3).

Because restricted gene flow implies only limited movement by individuals during any given generation, it takes time for a newly arisen haplotype to spread geographically, as suggested by Templeton (1998). Moreover, populations experiencing isolation-by-distance may share only part of their haplotypes. Hence, it is possible that in a continuum of populations, each one shares part of its gene pool with neighbouring populations (de Brito et al., 2002). This can be an explanation for the pattern observed in the haplotypes from clade 3-2 (Figure 2), which contained exclusively soybean haplotypes from northern Brazil and Phaseolus haplotypes from Cuba (17 and 21). This restricted gene flow scenario was particularly observed with Brazilian soybean AG-1 IA haplotypes (14, 15, 16, 


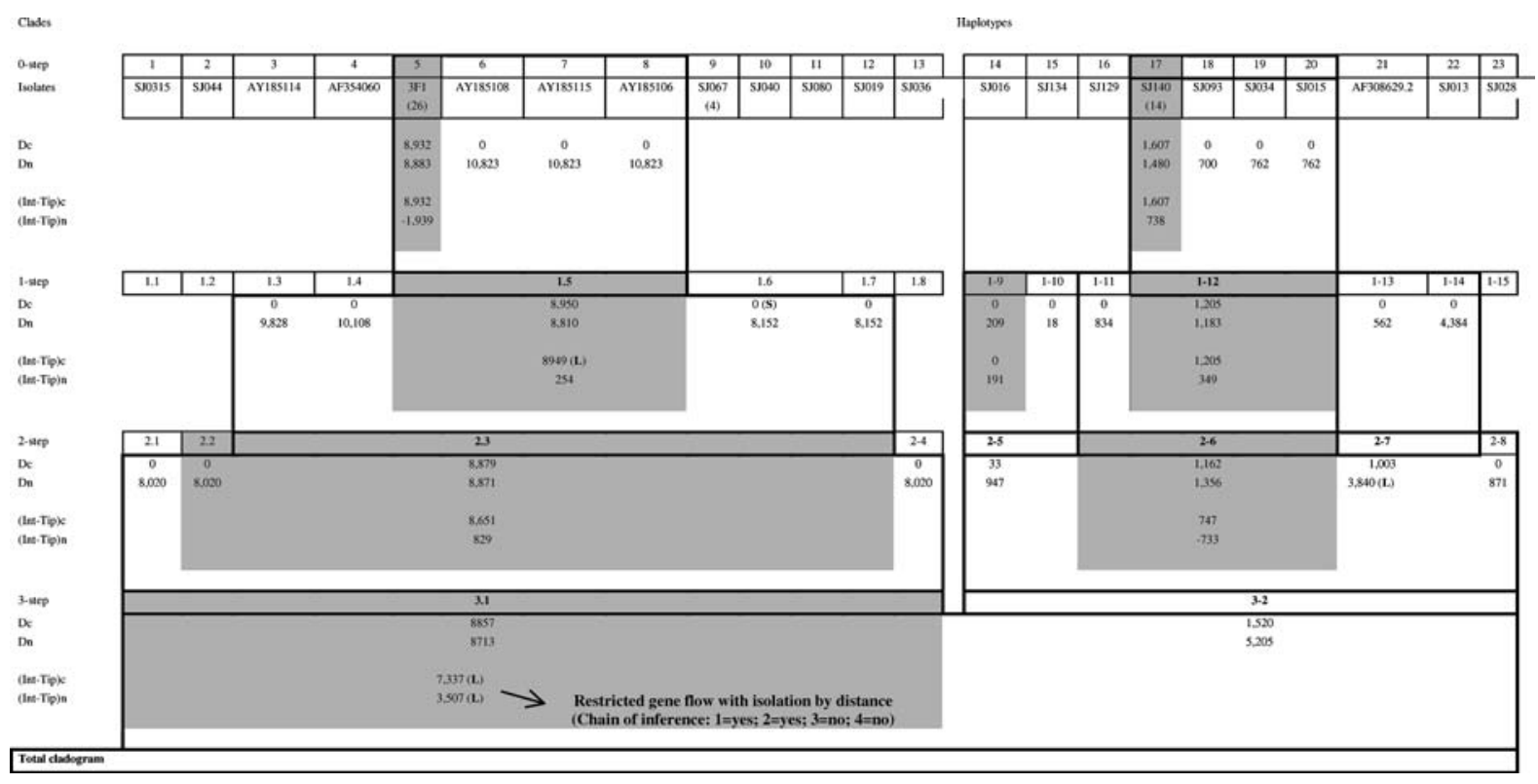

Figure 3. Results of the nested cladistic analysis of geographical distance for the ITS-5.8S rDNA haplotypes of $R$. solani AG-1 IA. The haplotype designations are given at the top and are boxed together to reflect one-step nested design given in Figure 2. Higherlevel clade designations are given as moving down the figure, with boxed grouping indicating the nesting structure. Immediately below each clade designation are the clade $\left(D_{\mathrm{c}}\right)$ and nested clade $\left(D_{\mathrm{n}}\right)$ distances respectively. $L$ indicates that it is significantly larger at $5 \%$. For nested clades in which the tip/interior status is known and for which both tips and interior exists within the same nesting groups, the clade name and distances are shaded for interior clades and are left non-shaded for tip clades. At the bottom of the boxes that indicate the nested groups containing both tip and interior clades the lines indicated by the symbols (Int-Tip)c and (Int-Tip $)_{\mathrm{n}}$ give the average difference in distances between the interior clades and tip clades within the nested group for clade distances and nested clade distances, respectively. The chain of inference for clades with significant historical pattern follows the key provided in the Appendix of Templeton (30): 1. Are all clades within the nesting clade found in separate areas with no overlap? Yes; 2. Is at least one of the following conditions satisfied? Yes, $d$. The I-T Dc is significantly larger; 3. Is at least one of the following conditions satisfied? For example, $(a)$. Some Dn and/or I-T Dn values are significantly reversed from the Dc values? No; 4. Are both of the following conditions satisfied? $a$. The clades (or 2 or more subsets of them) with significantly smaller De values have ranges that are completely or mostly non-overlapping with the other clades in the nested group (particularly interiors)? $b$. The pattern of completely or mostly non-overlapping ranges in the above condition represents a break or reversal from lower level trends within the nested clade series (applicable to higher-level clades only)? $N o=$ Restricted gene flow with isolation by distance (restricted dispersal by distance in non-sexual species).

$18,19,20,22$ and 23), the tip haplotypes connected to their most probable south-central ancestor, haplotype 17 , also from soybean.

These novel haplotypes of $R$. solani AG-1 IA from soybean could apparently have been generated by multiple mutations at the rDNA-5.8S region with each genotype representing unique single nucleotide mutations. If a mutation arises in a repeat unit of the array of rDNA copies, under a mechanism named concerted evolution, it is spread rapidly throughout the array by intrachromosomal homogenization mechanisms. This mutation is then spread further, by interchromosomal gene conversion (Liao et al., 1997; Liao 1999). This concerted mechanism implies the joint evolution of two or more related genes occurring as if they constitute a single locus. It is postulated that the homogenization of the rDNA tandem copies by the mechanisms of concerted evolution occurs during recombination events (Liao, 1999).

Our study reports, for the first time, the discrimination between historical events and ecological factors interfering with the current patterns of population structuring for a Rhizoctonia pathosystem. With Templeton's NCA on a network of AG-1 IA ITS-5.8 S haplotypes, we have derived the proper hierarchical testing from the data for detecting geographical associations. Because the nested analysis was able to discriminate between historical (past fragmentation, range expansion, colonization) and ecological factors (for example, recurrent gene flow) affecting the geographical 
distribution of genotypes of this important AG of $R$. solani, it should be the first step when investigating the evolution of any other $R$. solani AGs. As suggested by Templeton (1998), the nested geographical analysis coupled with the inference key provides an assessment of statistical significance, explicit inference criteria, and guidance to the researcher on how to collect future samples to make sound biological inference.

One could still question the importance of this molecular evolution study for this particular pathosystem if the distinct genotypes of $R$. solani AG-1 IA do not exhibit differences in pathogenicity, virulence, or some other trait phenotypes. However, the rate of molecular evolution is considered to exceed that of the morphological or physiological evolution (Couch and Kohn, 2002). As an example, M. oryzea and $M$. grisea, which are two distinct phylogenetic and biological species, have no detectable morphological differences between them. In the case of $R$. solani AG-1 IA, although no differences in pathogenicity were detected between the soybean and rice groups of the pathogen, there was clear indication that the distinct rDNA haplotypes are already distinct in terms of somatic compatibility grouping and RAPD genotyping (Fenille et al., 2002; Campos and Ceresini, 2005). No information is available concerning differences in virulence.

In our study, there was indication that several other haplotypes were not sampled from the soybean population of AG1 IA as indicated by black dots in the network of haplotypes (Figure 3). In addition, several tip haplotypes were sampled only once from the soybean $R$. solani AG-1 IA population. These observations suggest the need, in future studies, for increasing the sample size of the populations to improve the chances of sampling the totality of the haplotypes occurring and for increasing the power for detecting geographical associations at lower clade level. For better assessment of the variation that exists in populations of the pathogen, the analysis of other markers is warranted. This is especially true for the rice sample of the pathogen, as almost no variation was detected at the ITS-5.8S region of the rDNA in contrast to high levels of variation detected on seven distinct RFLP loci reported elsewhere (Rosewich et al., 1999). For a much broader view of historical events that explain the existing patterns of geographical association of haplotypes, a worldwide sample of $R$. solani AG-1 IA should be obtained.

\section{Acknowledgements}

We thank Dr. L. J. Herr (Ohio State University, Wooster, USA), Dr. S. Naito (Tohoku National Agricultural Experiment Station, Morioka, Japan) and Dr. S. Kuninaga (Health Science University of Hokkaido, Tohbetsu, Hokkaido, Japan) for supplying the tester isolates of anastomosis groups of $R$. solani. We also thank A. S. Prabhu (Embrapa, Centro Nacional de Pesquisa de Arroz e Feijão, Santo Antônio de Goiás, GO, Brazil) for supplying Brazilian isolates of $R$. solani from rice, and Dr. Yulin Jia (USDA-ARS-SPA, Dale Bumpers National Rice Research Centre, Stuttgart, AR, USA) for providing additional information on the origin of his rice isolates from Arkansas, with sequences deposited at NCBI.

\section{References}

Adams GC (1996). Genetics of Rhizoctonia species. In: Sneh B, Jabaji-Hare S, Neate S and Dijst G (eds) Rhizoctonia Species: Taxonomy, Molecular Biology, Ecology, Pathology and Disease Control (pp 101-106) Kluwer Academic Publishers, London

Almeida AMR, Ferreira LP, Yorinori JT, Silva JFV and Henning AA (1997) Doenças da soja In: Kimati H, Amorim L, Bergamin Filho A, Camargo LEA, Rezende JAM, (eds) Manual de Fitopatologia: doenças das plantas cultivadas Agronômica Ceres, vol. 2, chap. 61, pp.642-664 São Paulo

Amaral REM, Issa E, Souza DM, Malavolta VMA, Leite LC and Jesus LM (1979) Estudos sobre a queima das bainhas do arroz Oryza sativa L. Arquivos do Instituto Biológico 46: $55-62$

Banke S, Peschon A and McDonald B (2004) Phylogenetic analysis of globally distributed Mycosphaerella graminicola populations based on three DNA sequence loci. Fungal Genetics and Biology 41(2): 226-238

Bolkan HA and Ribeiro WRC (1985) Anastomosis groups and pathogenicity of Rhizoctonia solani isolates from Brazil. Plant Disease 69: 599-601

Campos APSC and Ceresini PC (2005) Somatic incompatibility in Rhizoctonia solani AG-1 IA from soybean. Summa Phytopathologica 31 (in press)

Carbone I, Anderson JB and Kohn L (1999) Patterns of descent in clonal lineages and their multilocus fingerprints are resolved with combined gene genealogies. Evolution 52: 1121

Carbone I and Kohn LM (2001) A microbial populationspecies interface: nested cladistic and coalescent inference with multilocus data. Molecular Ecology 10: 947-964 
Ceresini PC, Shew HD, Rosewich L, Vilgalys R and Cubeta MA (2002) Genetic structure of populations of Rhizoctonia solani AG-3 from potato in eastern North Carolina. Mycologia 94: 450-460

Ceresini PC, Shew HD, Vilgalys R, Gale LR and Cubeta MA (2003) Detecting migrants in populations of Rhizoctonia solani anastomosis group 3 from potato in North Carolina using multilocus genotype probabilities. Phytopathology 93: 610-615

Clement M, Posada D and Crandall KA (2000) TCS: A computer program to estimate gene genealogies. Molecular Ecology 9: 1657-1660

Couch BC and Kohn LM (2002) A multilocus gene genealogy concordant with host preference indicates segregation of a new species, Magnaporthe oryzae, from M. grisea. Mycologia 94: 683-693

de Brito RA, Manfrin MH and Sene FM (2002) Nested cladistic analysis of Brazilian populations of Drosophila serido. Molecular Phylogenetics and Evolution 22: 131-143

Fenille RC, Souza NL and Kuramae EE (2002) Characterization of Rhizoctonia solani associated with soybean in Brazil. European Journal of Plant Pathology 108: 783-792

Fenille RC, Ciampi MB, Kuramae EE and Souza NL (2003) Identification of Rhizoctonia solani associated with soybean in Brazil by rDNA-ITS sequences. Fitopatologia Brasileira 28: 413-419

Gonzalez D, Carling DE, Kuninaga S, Vilgalys R and Cubeta MA (2001) Ribosomal DNA systematics of Ceratobasidium and Thanatephorus with Rhizoctonia anamorphs. Mycologia 93: 1138-1150

Harville BG, Russin JS and Habetz RJ (1996) Rhizoctonia foliar blight reactions and seed yields in soybean. Crop Science 36: 563-566

Hillis DM, Moritz C, Porter CA and Baker RJ (1991) Evidence for biased gene conversion in concerted evolution of ribosomal DNA. Science 251: 308-310

Hudson RR and Kaplan NL (1985) Statistical properties of the number of recombination events in the history of a sample of DNA sequences. Genetics 111: 147-164

Hughe KW and Petersen RH (2001) Apparent recombination or gene conversion in the ribosomal ITS region of a Flammulina (Fungi, Agaricales) hybrid. Molecular Biology and Evolution 18(1): 94-96

James TY, Moncalvo JM, Li S and Vilgalys R (2001) Polymorphism at the ribosomal DNA spacers and its relation to breeding structure of the widespread mushroom Schizophyllum commune. Genetics 157: 149-161

Jones RK and Belmar SB (1989) Characterization and pathogenicity of Rhizoctonia spp. isolated from rice, soybean and other crops grown in rotation with rice in Texas. Plant Disease 73: 1004-1010

Kohn LM (2004) Applying comparative genomics to plant disease epidemiology. Phytoprotection 85(1): 45-48

Kozaka T (1975) Sheath blight in rice plants and its control. Review in Plant Protection Research 8: 69-80

Liao D (1999) Concerted evolution: Molecular mechanism and biological implications. American Journal of Human Genetics 64: 24-30

Liao D, Pavelitz T, Kidd JR, Kidd KK and Weiner AM (1997) Concerted evolution of the tandemly repeated genes encoding human U2 snRNA (the RNU2 locus) involves rapid intrachromosomal homogenization and rare interchromosomal gene conversion. EMBO Journal 16: 588-598

Linde CC, Zala M, Paulraj RSD, McDonald BA and Gnanamanickam SS (2005) Population structure of the rice sheath blight pathogen Rhizoctonia solani AG-1 IA from India. European Journal of Plant Pathology 112: 113-121

Menezes MLP (2001) A crise do Estado de bem estar e a caracterização de processos territoriais da migração no Brasil. Scripta Nova 94: 85

Meyer MC (2001) Caracterização de Rhizoctonia solani Kühn, agente causal da mela da soja [Glycine $\max (\mathrm{L}$.) Merrill], seleção de genótipos e controle químico. Botucatu. 138p. Thesis (Doutorado em Proteção de Plantas) - Faculdade de Ciências Agronômicas, Universidade Estadual Paulista

Meyer MC and Yorinori JT (1999) Incidência de doenças da soja em regiões tropicais. In: Congresso Brasileiro de Soja. Londrina. pp. 457 (Abstract)

Milgroom MG and Peever TL (2003) Population biology of plant pathogens - The synthesis of plant disease epidemiology and population genetics. Plant Disease 87: 608-617

Naito S, Mochida H, Nakajima T and Ohto Y (1995) Infection with basidiospores of Thanatephorus cucumeris (AG-2-3 of Rhizoctonia solani) and development of soybean foliar blight lesions. Annals of the Phytopathological Society of Japan 61: 362-368

Nei M (1987) Molecular Evolutionary Genetics, Columbia University Press, New York, 512

Pascual CB, Toda T, Raymondo AD and Hyakumachi M (2000) Characterization by conventional techniques and PCR of Rhizoctonia solani isolates causing banded leaf sheath blight in maize. Plant Pathology 49: 108-118

Phillips DV, Carbone I, Gold SE and Kohn L (2002) Phylogeography and genotype-symptom associations in early and late season infections of canola by Sclerotinia sclerotiorum. Phytopathology 92: 785-793

Posada D and Crandall KA (2001) Intraspecific gene genealogies: trees grafting into networks. Trends in Ecology and Evolution 1: 37-45

Posada D, Crandall KA and Templeton AR (2000) GeoDis: a program for the cladistic nested analysis of the geographical distribution of genetic haplotypes. Molecular Ecology 9: $487-488$

Rosewich UL, Pettway RE, McDonald BA and Kistler HC (1999) High levels of gene flow and heterozygote excess characterize Rhizoctonia solani AG-1 IA (Thanatephorus cucumeris) from Texas. Fungal Genetics and Biology 28: 148-159

Rozas J and Rozas R (1999) DnaSP version 3: an integrated program for molecular population genetics and molecular evolution analysis. Bioinformatics 15: 174-175

Sinclair JB and Backman PA (1989) Compendium of soybean diseases, 3rd edn. The American Phytopathological Society, Saint Paul, 106

Souza EC, Basseto MA, Prabhu AS and Ceresini PC (2005) Caracterização citomorfológica, cultural, molecular e patogênica de Rhizoctonia solani Kühn associada ao arroz em Tocantins, Brasil. Summa Phytopatologica 31 (in press)

Stroube WH (1954) Host range of Rhizoctonia aerial blight fungus in Louisiana. Plant Disease Reporter 38: 789-790

Templeton AR (1998) Nested clade analysis of phylogeographic data: Testing hypotheses about gene flow and population history. Molecular Ecology 7: 381-397 
Thompson JD, Gibson TJ, Plewniak F, Jeanmougin F and Higgins DG (1997) The ClustalX windows interface: flexible strategies for multiple sequence alignment aided by quality analysis tools. Nucleic Acids Research 25: 48764882

White TJ, Bruns T, Lee S and Taylor JW (1990). Amplification and direct sequencing of fungal ribosomal RNA genes for phylogenetics. In: Innis MA., Gelfand DH, Sninsky JJ and
White TJ (eds) PCR Protocols: A Guide to Methods and Applications (pp 315-322) Academic Press, San Diego, CA, USA

Yang XB, Berggren GT and Snow JP (1990) Seedling infection of soybean by isolates of Rhizoctonia solani AG-1, causal agent of aerial blight and web blight of soybean. Plant Disease 74: 485-488 